UDK 528.73

\title{
A COMPARISON TEST OF FEATURE EXTRACTION FROM AERIAL PHOTOGRAPHY
}

\author{
Birutė Ruzgienè \\ Dept of Geodesy and Cadastre, Vilnius Gediminas Technical University, \\ Sauletekio al. 11, LT-10223 Vilnius-40, Lithuania, \\ e-mail: Birute.Ruzgiene@ap.vtu.lt \\ Received 1207 2004; accepted 28092004
}

\begin{abstract}
All features visible in the aerial photographs can be collected by traditional photogrammetric methods; however, such techniques require high operator skills and are very time-consuming. The decision which photogrammetric method uses in mapping is primarily economic, also workload, project deadline requirements and accurate data have to be considered. Up-to-date developed automatic or semi-automatic systems are highly effective for $3 \mathrm{D}$ features extraction in urban areas. The investigation objective is the comparison of analytical and digital semi-automatic photogrammetric mapping methods for 3D building models extraction from aerial images analysing in time-consuming and in collected data accuracy consideration.
\end{abstract}

Keywords: stereoscopic plotting, aerial photography, digital photogrammetric system, image orientation, feature extraction, modelling.

\section{Introduction}

Aerial photogrammetry needs a series of the procedures including aerial photography, stereo-plotting, editing and output. Though mapping by aerial photogrammetry is rather expensive and slow in air flight as well as subsequent photogrammetric plotting and editing is very important for input accurate and upto-date spatial information.

Aerial photogrammetry offers two techniques nowadays mostly used for feature mapping: analytical and digital. In analytical photogrammetry a stereo pair of analog films is set up in a photogrammetric stereoplotter and the operator manually read terrain features. In digital photogrammetry aerial films are converted into digital image data with high resolution $(5-25 \mu \mathrm{m})$. Digital orthophoto is automatically generated with stereo matching using digital photogrammetric workstation. It is still very expensive but only a method for automated mapping. For identifying the patterns of houses, roads, structures and other terrain features automatically there is a need of image understanding.

Up-to-date photogrammetry offers new digital systems for collection 3D city models from aerial photography. Recently the development of telecommunication networks increased the needs for 3D urban models. The difficulty of reconstruction in urban environments is that the built-up areas are often very dense and involve many types of buildings.

All features visible in images can be modelled by traditional photogrammetric methods stereoscopically measuring on analytical plotter, but such approach requires high operator skills and is very time-consuming. Recently developed automatic systems for 3D objects extraction allows more rapid and simple site modelling on urban areas than the classical methods. The decision which photogrammetric method to use in mapping is primarily economic, although workload and project deadline requirements as well as accurate data have to be considered. Therefore the objective of research is the investigation of appropriate photogrammetric method for 3D building modelling from aerial photographs analysing in time-consuming and in collected data accuracy. The stereoplotter Wild A-8 Autograph was used for stereoscopic data capture. The introduced of electronic in the peripheral device of analogue stereoplotter Wild A-8 Autograph brought him closer to universal analytical stereoplotters. In addition a new semi-automatic feature extraction system InJECT was applied for measuring 3D buildings models from aerial photographs.

\section{Methodology}

Up to now classical photogrammetric methods has been used for collection of geometric data on features, though stereoscopic measurements on stereoplotters require different input data, high operator qualification, etc. A new digital technique for 3D automatic feature extraction from aerial photographs is recently suggested.

\section{1. Stereoscopic data capture}

The restitution of the spatial model formed by a stereo pairs of photographs requires pointing to the corresponding points on the overlapping pairs of photographs, a procedure which is most conveniently and accurately performed with the help of stereoscopy. Stereoscopic plotting instruments (stereoplotters) operations include making relative and absolute orientations to tie the mapping photography to ground control and plotting the map. These two operations 
produce a map that is accurate in scale and correctly portrays an area's topographic features.

The stereoplotters combine three distinct systems: 1) a projection system, which creates the true threedimensional stereo model; 2) a viewing system, which makes it possible for an operator to see that model; 3) a measuring (tracing) system, which enables measurements of the stereo model to be made and recorded [1].

The optical and mechanical components of stereoplotters are manufactured to a high degree of precision and accurate results may be obtained from them. The basic concept underlying the design of stereoplotters is illustrated in Fig 1. Diapositives are placed in two stereoplotter projectors. This process involves interior orientation. Light rays are projected through the diapositives and when rays from corresponding images on the left ant right diapositives intersect below they create a stereo model.

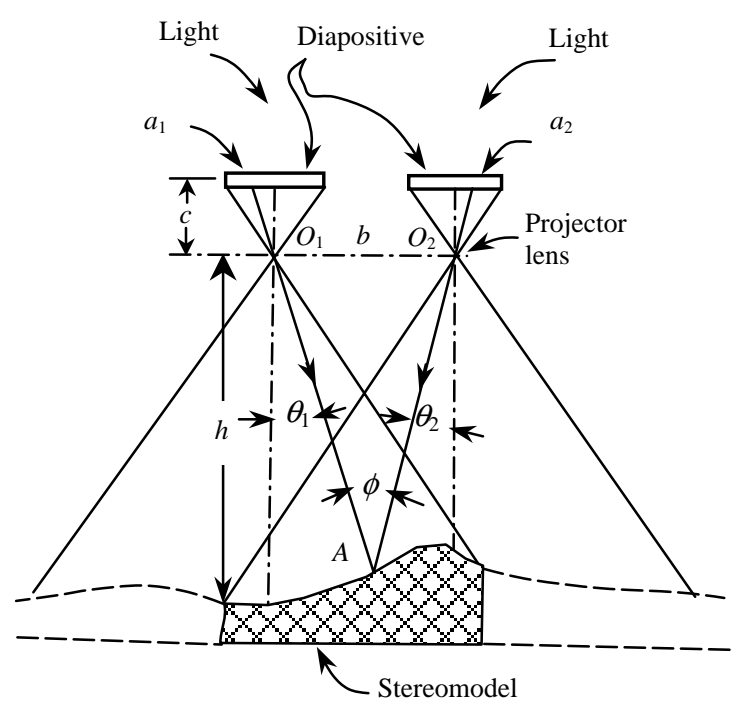

Fig 1. The concept of stereoscopic plotting instrument

By a process called relative orientation, the two projectors are oriented so that the diapositives bear the exact relative angular orientation to one another in the projectors that had in camera at the instant they were exposed. Relative orientation creates a true threedimensional stereomodel of the overlap area. After relative orientation is completed, absolute orientation is performed. In this process the model is brought to the desired scale and leveled with respect to reference datum. When orientation is completed, measurements of the model are made digitally. The position of any point is determined by bringing a reference mark into contact with the model point.

Accuracy of data collected by stereoscopic measurements depends of orientation procedures, number of control points, individual stereoplotters, film shrinkage, lens distorsion, etc.
The accuracy investigations of these data are based on a large number of empirical tests [2]. The planimetric accuracy of single points coordinates is directly proportional to the image scale with the exception of image motion of aerial photographs, $\mathrm{i}$ e, is constant referred to the photograph. Image motion influence accuracy when aerial photographs are of a very large scale. The type of camera plays insignificant role in determining the accuracy of the $\mathrm{X}$ and $\mathrm{Y}$ coordinates.

The height error $\hat{\sigma}_{z}$ is proportional either to the flying height (object distance) or to the square of this distance (the base $B$ and principal distance $c$ both remain constant, only the object distance $Z$ varies, when flight is over a stepped landscape or at different flying height). Mean square height error can be calculated [3]:

$$
\widehat{\sigma}_{z}=\frac{Z}{c} \frac{Z}{B} \hat{\sigma}_{p \xi}
$$

where $\hat{\sigma}_{p \xi}-$ accuracy of measured parallaxes.

The height error is linearly proportional to the object distance when the ratio $B / Z$ and principal distance is constant or photo scale number $Z / c$ and the base $B$ is constant. Such proportionality is valid only for normalangle and wide-angle camera. The relation between the height error and object distance is weaker for superwide-angle cameras.

The accuracy parameters of signalised points, used as a standard, are:

- accuracy of planimetric coordinates $\widehat{\sigma}_{X Y}=6 \mu \mathrm{m}$;

- accuracy of height $\hat{\sigma}_{z}= \pm 0,06 \%$ of the flying height above ground.

The empirical approach for determination of accuracy can be applied for natural points: corners of buildings and fields, trees, etc. In such case the accuracy of the point $\hat{\sigma}_{\text {def }}$ has to be added [3]:

$$
\begin{aligned}
& \hat{\sigma}_{X Y n a t}=\sqrt{\hat{\sigma}_{X Y s i g n}^{2}+\hat{\sigma}_{X Y d e f}^{2}} . \\
& \hat{\sigma}_{\text {Znat }}=\sqrt{\hat{\sigma}_{Z s i g n}^{2}+\hat{\sigma}_{Z d e f}^{2}} .
\end{aligned}
$$

The accuracy of definition of some types of natural points is shown in Table 1.

Table 1. Error of natural points definition

\begin{tabular}{|l|c|c|}
\hline Type of point & $\hat{\sigma}_{X Y}, \mathrm{~cm}$ & $\widehat{\sigma}_{Z}, \mathrm{~cm}$ \\
\hline Natural & & \\
building corners & $7-12$ & $8-15$ \\
field corners & $20-100$ & $10-20$ \\
trees and bushes & $20-100$ & $20-100$ \\
\hline
\end{tabular}

The estimated accuracy presented in Table 1 can be reached collecting data by stereoplotters and stereocomparators. Very exactly selected or artificially marked points can be measured with almost the same accuracy as for signalised points. 


\subsection{Automatic feature extraction from aerial photographs}

Automated feature extraction strategies are categorised according to their degree of automation into semi- or fully automatic. The objective of semiautomatic methods is to help the operator in real time. Feature extraction research is focused on features (mainly on buildings) that are most useful in GIS application and that are the most time-consuming for manual extraction. Feature extraction systems provide three-dimensional feature composed of points, lines and polygons [4]. Approaches to automated building extraction combine photogrammetric principles with CAD-based site modelling. The building structure is preceded by extracting from the image primitives. These primitives may range from points and lines to surface elements (Fig 2). a)

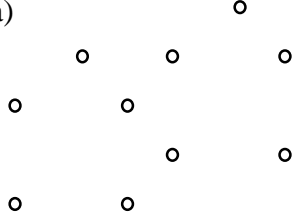

b)

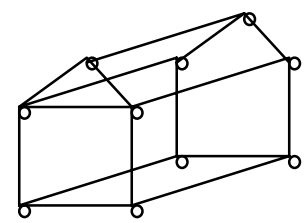

Fig 2. Building representation: a) points, b) wire frame

The roof structure of a building is fundamental model consideration and can be classified into such categories: flat, peaked and gable. Compilation of building structure is based on a particular digitising sequence for each roof type. For example, the operator digitises three points to complete a flat roof building and a peaked or gabled roof requires four or six digitised points.

Evaluating the performance of automatic or semiautomatic feature extraction, it is commonly measured by comparing algorithm output against a manual derived ground truth [5]. Human error may be introduced in the determination of extracted data accuracy. Various accuracy measures are used. Commonly three used measures include: 1) correctness; 2) completeness and 3) quality $[6,7]$.

\section{Practical performance on the test field}

Aerial photographs over Vilnius city at a scale of 1:6000 were used for practical investigation. Aerial photographic mission was preceded in 1995 with camera RMK TOP. Camera's focal length $c=153,6 \mathrm{~mm}$. Flying height $H=910 \mathrm{~m}$.

Test field - aerial photographs of Antakalnis region of Vilnius city. Aerial images (test model) are covering an area of approximately two square kilometer. Buildings cover an area about $30 \%$.

Images for digital building extraction were scanned with pixel size $12 \mu \mathrm{m}$ and inner-outer orientation has been done at Photogrammetry institute of Bonn University using digital photogrammetric workstation PHODIS Zeiss.
Automatic feature extraction. 3D building models (3D wireframes) has been measured by semi-automatic feature extraction digital system InJECT, developed at the Photogrammetry Institute of Bonn University supervising by Prof Dr-Ing W. Förstner. The user of InJECT is supported by tools with scalable degree of automation for rapid site modelling [8].

Three digital images $\left(\mathrm{N}^{0}\right.$ 228, 229 and 230) were used for navigation and building extraction (see Fig 3, 4). There were extracted founded 68 Constructive Solid Geometry trees ( 75 primitives) mostly with saddleback and boxes roof buildings. The three-dimensional data acquisition has been performed by an inexperienced operator after half week training.

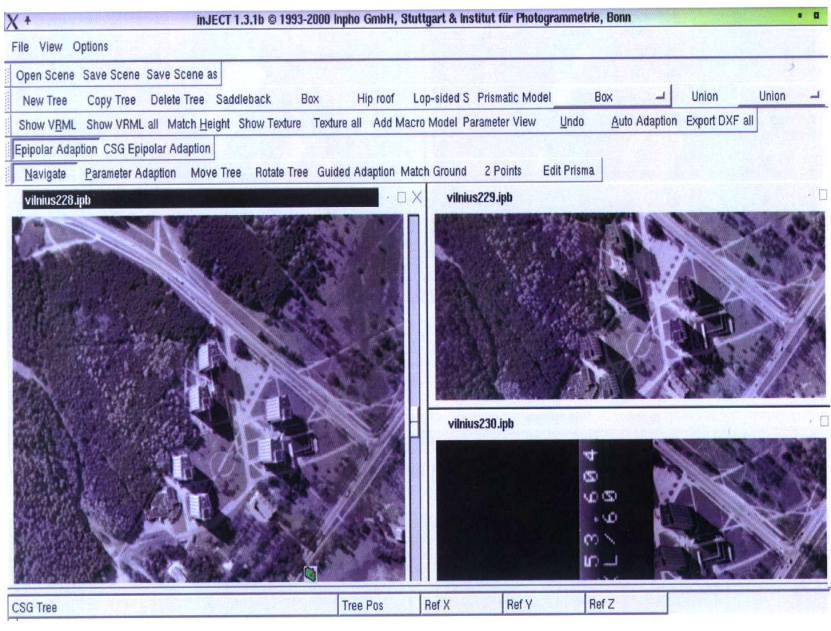

Fig 3. Fragment of the test field for building extraction

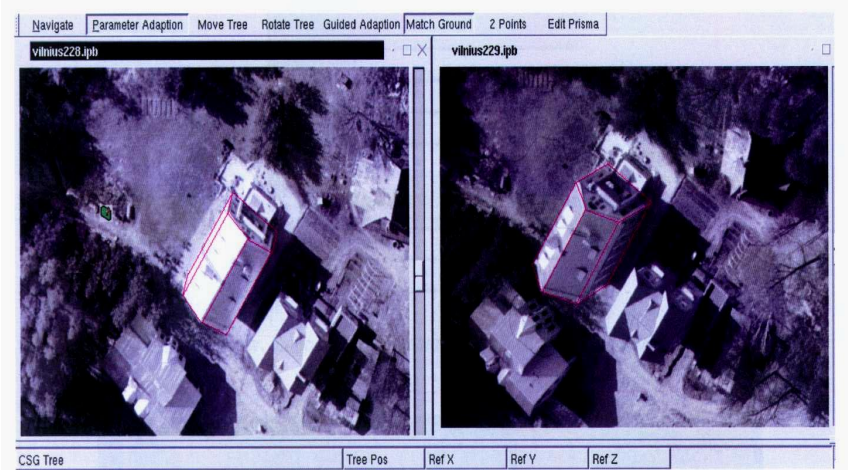

Fig 4. Adaptation of a wire-frame model

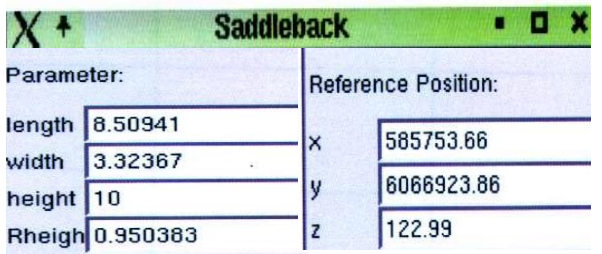

Fig 5. Parameterisation of a saddleback building

Semi-automatic building extraction was based on monocular measurements using overlapping images, fitting shape and height (Figs 5, 6). 


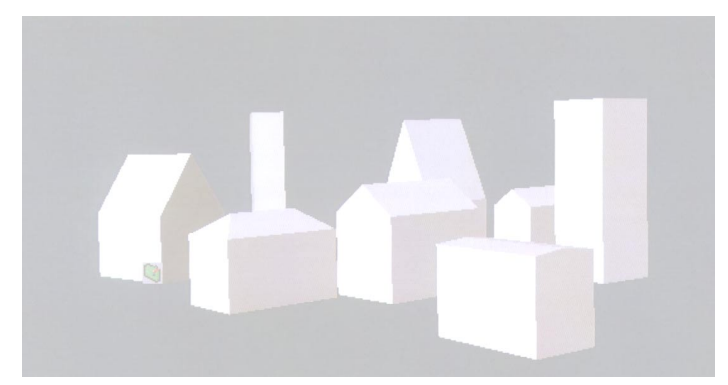

Fig 6. Visualisation of extracted buildings 3D model on the test field

Stereoscopic measurements. Stereoplotter Wild A-8 Autograph with introduced of electronic encoders in this peripheral device was used for stereoscopic building extraction. The digitising of features (3D data collection) on the test field has been made using Norwegian software PUMATEC PSdig. Such technique was used at Geodesy Institute of VGTU when the reference database of city Vilnius has been created stereophotogrammetrically.

72 buildings with different types of roof were measured on the stereo model of test field stereoscopically. Fragment of extracted features is shown in Fig 7.

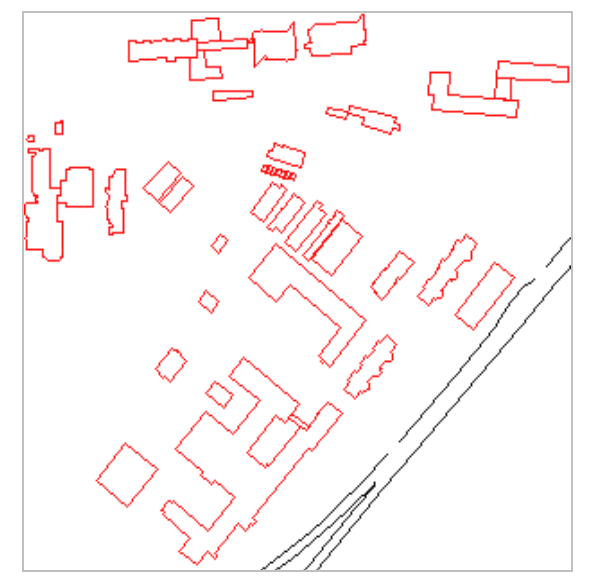

Fig 7. Fragment of stereoscopic data capture on the test field

\section{Comparison results}

Building extraction evaluation includes comparison of the time and operator effort required as well as accuracy of data acquired by the semi-automated system and manual methods [9]. The time for model creation consists of:

- measurement or modification building models;

- $\quad$ adjustment of view, zooming windows, etc;

- automatic processes;

- examination of the imagery, planning the types of models to use or verifying the solution results.

Semi-automated building extraction system generates correct building geometry, since the operator is guiding the process, therefore involves the amount of time required, either a huge editing time required for correction.
In the comparison (evaluation), the goal was to give an estimate of the efficiency of building extraction by the automation technique. Buildings are the most complex feature to extract, due to their variety of complex shapes and appearances, the high probability of occlusion by surrounding objects. A comprehensive evaluation of test site was undertaken and such disadvantages of usage the digital system for 3D feature extraction have been found:

- several buildings (about $5 \%$ ) have a complicated roof shape;

- difficulties to detect the roof edge angle of buildings situated in the centre of photographs;

- about $20 \%$ of buildings were covered by shadows and vegetation and about $30 \%$ of buildings the ground position could not be observed clearly;

- determining the type of buildings need more time for interpretation of building's geometry because of not having possibility to display more images.

Recording the time required for each operation of building extraction, this can be divided into such categories: operator time (modelling), when the operator is actively measuring or modifying models; admin time (local navigation), when the operator is adjusting the view, zooming window, etc; system time, when the automated processes or photogrammetric solution is executing; and cognitive time (global navigation), when the operator interacting with computer but instead examining the imagery.

The 3D modelling time in comparison of semiautomatic with classical photogrammetric method could be significantly reduced. The recorded time during experiment is shown in Table 2.

Table 2. Average time for 3D modelling in the test field

\begin{tabular}{|c|c|c|}
\hline \multirow[t]{2}{*}{$\begin{array}{l}\text { Components of time for } \\
\text { building extraction }\end{array}$} & \multicolumn{2}{|c|}{$\begin{array}{c}\text { Time per primitive } \\
\text { (seconds) }\end{array}$} \\
\hline & $\begin{array}{c}\text { Semi- } \\
\text { automatic }\end{array}$ & Analytical \\
\hline Global navigation & 30 & 50 \\
\hline Local navigation & 20 & 35 \\
\hline Modelling & 55 & 95 \\
\hline Editing & 30 & 20 \\
\hline Visualisation and correction & 15 & 10 \\
\hline Total & $\begin{array}{c}150 \\
(2,5 \mathrm{~min})\end{array}$ & $\begin{array}{c}210 \\
(3,5 \mathrm{~min})\end{array}$ \\
\hline
\end{tabular}

Comprising both manual and semi-automated processes the use of automated processes reduced the elapsed time by about $30 \%$ as well as user efforts reduced significantly.

The accuracy of extracted features by automatic technique depends on: image scale, pixel size, orientation procedures, film processing, scanning, selection and measurement of models and homologous points, identification of buildings corners, generalisation of elevation.

The investigation of accuracy on the test field was based on discrepancies of measured roof point coordinates and ground point coordinates (differences 
between data acquired by automatic building extraction and analytical stereophotogrammetrical method). The created test model includes 56 points of identifiable building corners. The determined accuracy is:

\begin{tabular}{cc}
\hline Position error & Height error \\
\hline $32 \mathrm{~cm}$ & $40 \mathrm{~cm}$ \\
\hline
\end{tabular}

Such result corresponds to the accuracy of analytical photogrammetric methods taking into consideration the investigated accuracy of stereophotogrammetrically formed Vilnius city reference data base which was received up to $26-34 \mathrm{~cm}$ for planimetric coordinates and accuracy of point elevations - $14 \mathrm{~cm}$ [10] as well as referring to section 2.1 .

\section{Conclusions}

Automatic extraction of 3D buildings from aerial photographs allows a more rapid acquisition of 3D data in urban areas than the classical analytical photogrammetrical method. Such method does not require highly experienced human operator as well.

In comparison with stereophotogrammetrical method the digital feature extraction system is more flexible and efficient for 3D building modelling. The 3D data acquisition time reduces by about $30 \%$ when using the semi-automatic building extraction system.

The accuracy of extracted 3D data corresponds to classical analytical photogrammetrical methods. However, evaluation of building extraction performance requires a number of different data sets and a very accurate reference model.

\section{References}

1. Edited by Russell, C. Brinker and Roy Minnick. The Surveying Handbook. Boston/Dordrecht/London: Kluwer Academic Publishers, 2001. 929 p.

2. Čekanavičius, V.; Murauskas, G. Statistics and application (Statistika ir jos taikymai), Vol I, Vilnius: TEV, 2000. 238 p. (in Lithuanian).

3. Kraus, K. Photogrammetry. Vol 1. Fundamentals and Standard Processes. Köln: Dümmler, 2000. 396 p.

4. Editor McGlone, J., Chris. Manual of Photogrammetry. Fifth Edition. American Society for Photogrammetry and Remote Sensing, Maryland, USA, 2004. 1151 p.

5. Fraser, C.; Baltsavias, E.; Gruen, A. Processing of Ikonos Imagery for Submetre 3D Positioning and Building Extraction. ISPRS Journal of Photogrammetry and Remote Sensing, No 56, 2002, p. 177-194.

6. McKoewn, D.; Bulwinkle, T; Cochran, S; Harvey, W; McGlone, C. and Shufelt, J. Perfomance evaluation for automatic feature extraction. International Archives of Photogrammetry and Remote Sensing, Vol XXXIII, Part B2, Amterdam, The Netherlands, 2000, p. 379-393.

7. Baillard, C. and Zisserman, A. A plane-sweep strategy for the reconstruction of buildings from multiple images. International Archives of Photogrammetry and Remote Sensing, Vol XXXIII, Part B2, 2000, p. 56-62.

8. Förstner, W. 3D-City Models: Automatic and Semiautomatic Acquisition Methods. Photogrammetric Week 1999, Stuttgart, 1999, p. 291-303.
9. Ruzgienè, B. Some aspects on semi-automatic extraction of buildings from aerial photographs with the use of InJECT system. Geodesy and Cartography (Geodezija ir kartografija), Vol XXVII, No 1. Vilnius: Technika, 2001, p. 3-9.

10. Žalnierukas, A. Vilnius stereophotogrammetric digital map and peculiarities of its utilisation. Geodesy and Cartography (Geodezija ir kartografija), Vol XXVI, No 1. Vilnius: Technika, 2000, p. 24-31 (in Lithuanian).

\section{OBJEKTU MODELIAVIMO IŠ AEROFOTONUO- TRAUKŲ METODŲ PALYGINIMAS}

\section{B. Ruzgienè}

S a n trauka

Visi objektai, matomi aerofotografinèse nuotraukose, iki šiol yra kartografuojami klasikiniais fotogrametriniais metodais, tačiau tai užima daug laiko bei reikalingi aukštos kvalifikacijos operatoriai. Dabar yra sukurta automatinių arba pusautomačių sistemų objektų trimačiams modeliams iš fotonuotraukų kurti. Kadangi erdvinių statinių, ypač miestų teritorijose, modeliu kūrimo poreikis ateityje didès, sprendžiama, kuris metodas objektu erdvinei padéčiai nustatyti yra efektyvesnis, atsižvelgiant $\mathfrak{i}$ ekonomines sąlygas, laiko sąnaudas bei tikslumo reikalavimus.

Analizuoti du fotogrametrinio kartografavimo metodai statiniu erdviniams modeliams sudaryti: analitinis ir pusiau automatinis. Metodai palyginti, atsižvelgiant ỉ laiko sąnaudas bei gautujų duomenų tikslumą.

Eksperimentiniai bandymai atlikti pagal Vilniaus miesto 1: 6000 mastelio aerofotografines nuotraukas. Fotogrametriniai statinių erdviniai matavimai atlikti naudojant pusautomate skaitmeninę sistemą InJECT ir taip pat analoginị stereografą Wild A-8 Autograph su Pumatec PSdig programine iranga. Pateikta statiniu modeliavimo metodika bei fotogrametrinių matavimu fragmentai (̌̌r. 3, 4, 5, 6 ir 7 pav.)

Atlikus eksperimentinius tyrimus nustatyta, kad trimatis objektuc modeliavimas, naudojant skaitmeninius fotografinius vaizdus, pusiau automatiniu metodu yra apie $30 \%$ spartesnis nei analitiniu stereofotogrametriniu metodu (žr. 2 lentelę). Ištirta, kad sumodeliuotujų pastatų padèties tikslumas atitinka klasikiniais fotogrametriniais metodais atliekamų matavimų tikslumo reikalavimus. Šiuos tyrimus reikètu tęsti, suformavus daugiau tikslių referencinių modelių bei atsižvelgiant $\mathfrak{i}$ gaunamų duomenų išsamumą ir kokybę.

Raktažodžiai: stereoskopinis braižymas, aerofotografavimas, skaitmeninès fotogrametrinès sistemos, vaizdų orientavimas, duomenų surinkimas, modeliavimas. 